First Peoples Child \& Family Review

A Journal on Innovation and Best Practices in Aboriginal Child Welfare Administration,

Research, Policy \& Practice

\title{
A Change of Residence: Government Schools and Foster Homes as Sites of Forced Aboriginal Assimilation - A paper Designed to Provoke Thought and Systemic Change
}

\section{Cathy Richardson and Bill Nelson}

Volume 3, Number 2, 2007

Special Issue: Adolescent development, mental health, and promising research directions for Aboriginal youth

URI: https://id.erudit.org/iderudit/1069466ar

DOI: https://doi.org/10.7202/1069466ar

See table of contents

Publisher(s)

First Nations Child and Family Caring Society of Canada

ISSN

1708-489X (print)

2293-6610 (digital)

Explore this journal

Cite this article

Richardson, C. \& Nelson, B. (2007). A Change of Residence: Government Schools and Foster Homes as Sites of Forced Aboriginal Assimilation - A paper

Designed to Provoke Thought and Systemic Change. First Peoples Child \&

Family Review, 3(2), 75-84. https://doi.org/10.7202/1069466ar 


\title{
A Change of Residence: Government Schools and Foster Homes as Sites of Forced Aboriginal Assimilation - A paper Designed to Provoke Thought and Systemic Change
}

\author{
Cathy Richardson and Bill Nelson
}

\section{Introduction}

Richard Cardinal is a Metis boy from Fort Chipewyan. He now resides in the spirit world, along with many other Aboriginal children, after hanging himself from a birch tree in Alberta in the backyard of his sixteenth foster home. Richard is not forgotten, but reminds advocates for Metis children, Aboriginal children, all children, that we are in the midst of an ongoing crisis when it comes to caring for "removed" children. Not unlike many children in the care of the state today, Richard had been removed from his parents, removed from his home community, and finally separated from his siblings without his consent. He was placed in twenty eight different living situations: these included sixteen foster homes, twelve group homes and locked facilities, as well as time spent on the street while trying to escape from abusive foster parents. He died at age seventeen. It was a Metis organization that brought Richard's plight into the public eye. The abuse, degradation, and inhumanity endured by this Metis child was exposed. However, in spite of his suffering, he was ostracized in the system for being difficult, while he became more and more suicidal.

By the age of nine, Richard was in his eleventh foster home. After being separated from his siblings, no one bothered to let them know his whereabouts. In his suicide he wrote:

I'm skipping the rest of the years because it continues to be the same.

I want to say to people involved in my life, don't take this personally -

\section{I just can't take it anymore.} today.

Tragically, we still hear of similar situations

The authors of this paper both experienced a particular resonance with the life of Richard Cardinal. Richard came from the same community as Cathy's mother, Fort Chipewyan; Bill worked at a northern Alberta Child and Family serving agency that was held partly responsible for letting Richard fall through the cracks. Both the authors felt moved to influence child welfare practice in ways that respect the integrity of family and Aboriginal communities. However, the colonial structures of the child welfare machinery are geared to facilitate the removal of children from family through practice, policy and Canadian law. Attempts to honour and empower extended family systems to care for their own young ones continue to be met with systemic obstacles, as well as to go against the historical grain. As we move from interning children in the prisons called Residential Schools to foster homes, are we merely changing the residence of Aboriginal assimilation in Canada? And will child welfare be the last site of forced assimilation while many Canadians aspire to de-colonize and renegotiate the social contract between non-Aboriginal and Aboriginal peoples? This paper will address some of the similarities of these two residential structures that have housed hundreds of thousands of Aboriginal children when they are removed from their people. 


\section{From Residential Facility to Residential Facility}

In the 1960s, the Canadian government extended its assimilation from education into the realm known as child welfare. Through changes in the Indian Act, social workers received a legal mandate for a foray into Native reserves to remove Aboriginal children from their parents. In response to these changes, Patrick Johnson (1983) coined the term "The Sixties Scoop" to describe the mass redirection of Aboriginal children into European-Canadian residences and communities, as well as into adoptive homes abroad. The authors of this paper are startled by the unsettling qualitative similarities between the residential school and the present day foster residences, from a systemic perspective related to processes of cultural assimilation. We do not assert that individual foster parents possess the general intent or values found in the Canadian residential schools. Foster caregivers are often nurturing and loving individuals who aspire to provide quality care to their wards. However, the systemic practice of moving children through the world of foster houses and group homes can leave Canadian youth scathed and traumatized.

The research has shown that Aboriginal children in foster or adoptive families tend to experience greater wellness and offset mental/emotional/physical and spiritual illness when they remain connected to their natural families (Carriere, 2006; 2005a, 2005b). Carriere's (2005) doctoral research in Alberta showed that "all 18 participants described that their need to know their birth family stemmed from longing to know who they are and where they came from" ( $p$. 547). This connection to family has been recognized as integral for child wellness that is it recognized in the United Nations Convention on the Rights of the Child:

1. All children have the right to a legally registered name, the right to nationality and the right to know and, as far as possible, to be cared for by their parents.

2. Governments should respect children's rights to a name, a nationality and family ties.

3. Children should not be separated from their parents unless it is for their own good, for example if a parent is mistreating or neglecting a child. Children whose parents have separated have the right to stay in contact with both parents, unless this might hurt the child. http://www. anationalvoice.org/rights/rotch./2.htm

The Royal Commission on Aboriginal Peoples Gathering Strength (1996) states the following about extra cultural fostering and adoption:

\begin{abstract}
The removal of Aboriginal children from their communities through cross-cultural foster placement and adoption is a second major cause of family disruption. Children removed from their families are severed from their roots and grow up not knowing what it is to be Inuit, Metis or a First Nation member. Yet they are set apart from their families and communities by visible difference and often made to feel ashamed of their origins. At the same time, their home communities and extended families are robbed of part of the next generation (www.ainc. gc.ca/sh/recap/rpt/gs_e.html)
\end{abstract}

A recent study in British Columbia (Morley \& Kendall, 2006) found that children in the child welfare system in B.C. are far more likely to suffer serious physical and mental health problems. Youth in care are 4.5 times more likely to die preventable deaths than those not in care. They are also more likely to suffer respiratory problems, to get pregnant, and to abuse alcohol and drugs. Sixty-five percent of children in care have been diagnosed with a mental disorder, compared to only $17 \%$ of children in the general population.

The research indicates that youth in the child welfare system tend to move back to their birth family as soon as they are cut loose from the child welfare authorities - that is if their familial connections were not completely severed by social work practice. Babb, L.A. (1996) in "Statistics on U.S. Adoption: The Decree" by the American Adoption Congress, reported that $72 \%$ of adopted adolescents wanted to know why they were adopted and $65 \%$ wanted to meet their birth parents. Courtney and Piliavin (1998) reviewing Wisconsin youths who were emancipated from foster care found that many had contact with natural families after discharge and that one-third were living with their families. Cook (1991) reported that the population of emancipated youth leave the system 
with considerable issues: $2 / 3$ had not completed high school, $61 \%$ had no job experience, $38 \%$ had been diagnosed as emotionally disturbed, $17 \%$ had a drug abuse problem and $17 \%$ of the females were pregnant. In a follow-up study conducted $2.5-4$ years after leaving foster care only $50 \%$ had completed high school, less than half had jobs, $60 \%$ of the females had given birth and fewer than $20 \%$ were completely self-supporting.

Working for an Aboriginal child and family social services agency, the authors have witnessed various approaches to child welfare. Although some approaches could be called more 'humanistic' than others, it is rare that fostering arrangements are put in place which honour the child's familial and cultural relationships. There are two crucial issues related to such broken connections. Firstly, many fostering arrangements involve the ongoing movement of peoples who have been assimilated into EuropeanCanadian families, thus depleting Aboriginal nations of citizens and loved ones. Aboriginal agencies are allotted minimal budgets to do the "mopping up" of the state decisions, to relieve the suffering of individuals and families in the wake of a multitude of losses. Keeping focused on "problem-solving" redirects energy from tasks of visioning and advancing Aboriginal sovereignty through treaty negotiating and nation building.

Secondly, while there are always rational explanations about why familial connections cannot be maintained, these ruptured relationships are often stated to be severed "in the best interest" of the child. Sometimes, these 'attenuated' relationships involve practice compromise where workers have not exercised the full range of possibilities to keep family members in contact with each other in alignment with a more collectivist worldview, where limited work time and resources undermine best practice standards and Aboriginal cultural consultants are not engaged in most cases involving Aboriginal children. Relationships with the natural/birth family are attenuated in order to create a new bond with what is called "The Forever Family" (http://www.mcf.gov. bc.ca/minister/archived/speeches/adoption.htm).

However, perhaps most relevant to this point is that the severing of family attachments seems to be perceived as a means of facilitating adoption, and adoption, i.e. permanency, is considered by many to be in the best interests of the child (Carriere, 2005; Yellowhead Tribal Council, 2000). So, it is not an issue that severing the child's family relationships per se is in the best interests of the child but instead that the outcome of severing these relationships allows for less encumbered adoptions in mainstream adoption practice (e.g. for non "custom care" adoption, Yellowhead Tribal Council, 2000). For example, in British Columbia parents may request an "Access" order in the case of adoption, but child protection workers tend to oppose these orders on the assumption that it will make it more difficult to find adoptive parents, a belief that is yet not proven in the research (Seaborn, 2007, personal communication). Given that Aboriginal families are disadvantaged by the structure of state-perpetuated power relations and shrinking social net, they have little recourse to contest such impositions.

\section{A Brief Look at Residential School}

\section{Internment}

When the Canadian government, through its department of Indian affairs, established an internment system known as "residential school" in advance what Indian Affairs Superintendent Duncan Campbell Scott called "the final solution of our Indian problem," (RCAP film "No Turning Back", 1996; Cameron, Davis, Nixon \& Ruemke, 2006, p. 3) these educational responsibilities were contracted out to religious organizations such as the Anglican and Roman Catholic churches. Under a policy known as "aggressive civilization" (Wade, 1995, p. 171) Campbell Scott was first noted using the words "the final solution" when deciding to remain inactive to the high levels of deaths in the schools due to the spread of tuberculosis (Annett, 2002). Of the approximately 100,000 children who were interned, researcher and writer Kevin Annett (2002) estimates that 50\% of the interned children died as a result of the various forms of abuse and disease.

The removal of Aboriginal children was one arm of the colonial attack on Aboriginal communities: the destabilization caused by the forced removal of children (reminiscent of earlier introductions to alcohol in the context of ongoing imperial takeover) 
facilitated the transfer of Aboriginal lands and resources into the hands of the Crown and mining and land companies. Residential Schools were operated for over a hundred years, providing intensive and systemic resocialization and cultural deprogramming for Aboriginal children while inflicting endless grief onto Aboriginal communities. While most residential institutions had closed by 1980 , the last D.I.A. funded school remained open up to 1990 (Cameron, Davis, Nixon \& Ruemke, 2006, p. 3).

Today, many parents of children who come to the attention of the child protection system are described with the same colonial discourse used to justify publicly the forced internment of children. They are described as lacking the skills, resources, and expertise needed to parent their children. Aboriginal families are subjected to policies based on the colonial foundations that structure many of the WhiteAboriginal relationships and government services. Wade (1995) identifies "a very close and mutually supportive relationship between colonialism and the so-called "helping professions". This colonial code of relationship is outlined as follows (Wade, 1994, p. 45):

1) You are deficient/I am proficient;

2) Therefore, I have the right (duty, privilege, responsibility) to perform prescribed operations upon you, with or without your consent;

3) These operations are undertaken for your own good.

In his work as social work supervisor at an Aboriginal child welfare agency, Bill Nelson has observed the dynamics and practices that facilitate the child removal process in regards to Aboriginal families. After removal, these children tend to be assigned to a European-Canadian residence. Nelson has outlined "The Seven Steps To Child Removal" which constitute part of the machinery that prevent Aboriginal families and advocates from challenging successfully the loss of parental rights (except in the few cases where parents have managed to cultivate the good opinion of their worker). These steps are as follows, and are often enacted after a mother has approached the Ministry for help with poverty or substance use related to grief or spousal violence and the child is taken into temporary care:

1) the Aboriginal child is said to be "special needs"

2) the mother/parent is assigned a diagnosis in accordance with the DSM IV

3) an "expert" (psychologist) is called in to develop a report, often out of any cultural or ecological context

4) the report confirms that because the child is "special needs" s/he requires a caregiver with specific expertise; because the parent has a diagnosis they clearly are not the one to raise the child

5) the mother/parents' visits are deemed to cause grief for the child and are thus "attenuated"; the relationship with the new caregivers becomes the focus

6) the diminished connection between the parent and child is then blamed on the mother

7) the child is taken into permanent care of the Ministry and placed in a foster residence while adoption is considered; parental rights are terminated.

\section{Healing From Residential Internment}

There are differing perspectives about the success and nature of these DIA- administered institutions. While Aboriginal people across Canada continue to query about who it was exactly that gave the Canadian government the mandate for Indian education, and how that could have been done without the express permission of Aboriginal people, the Canadian government is now acknowledging that the schools were a mistake. However, there is a lot at stake related to Aboriginal healing and the responsibility of the state for acts of apology and restoration. While George Erasmus has said, many Aboriginal people feel they have not had the definitive opportunity to tell their story of their history from their perspective; 
the Canadian public remains largely unaware of the state-imposed violence and genocide towards Aboriginal people. Unlike Australia, we have had no National Sorry Day (Kinnear, 2002) and Aboriginal people have not been witnessed collectively for the injustices enacted towards them. Blackstock et al identify a non-linear process involving Truth Telling, Acknowledging, Restoring and Relating" as key aspects of Aboriginal related, also related to a larger renegotiation of the social contract between non-Aboriginal and Aboriginal peoples (Blackstock et al 2005). However the Canadian government still refuses to grant universal compensation or to grant an apology to the school's victims, nor to initiate a movement towards restitution and reconciliation.

\section{The Elimination of Aboriginal Culture}

In this section the acronym "LRS" will be used in parentheses to say "Like Residential Schools". For example, the authors have noted that mainstream Canadian foster families do not speak Aboriginal languages (LRS). Many foster families are Christians (LRS). Many foster families do not teach about Native spirituality, attend ceremonies and encourage foster children to honour their ancestors, spirit guides and the four directions (LRS).

In many mainstream Canadian foster homes children are loved and nurtured. They are taught values from some moral code and are encouraged to "work". In the past, children's work was of a productive nature: children often did chores and helped gain income. In residential schools Aboriginal children were the housekeepers: they washed floors, sewed and mended clothing and textiles, prepared food, cleaned toilets, dusted, polished and acted as handmaidens/servants for priests and nuns. Today, a child's job is to "play". So, in many foster homes children are kept busy with child's play, which often seems to be watching videos, playing videogames, in a bedroom. Children are kept on a busy schedule - a schedule that could not be maintained or supported financially by the birth family. This schedule often involves more child work, such as swimming lessons, dancing, piano, scouts, softball, soccer, etc. Most profoundly, children in residential school were largely denied access to their families. Today, Aboriginal children who have been removed from their birth families are "weaned" away from their family in order to bond with a new foster family or prospective adoptive parents.

Child protection and adoptions and guardianship workers for the B.C. child welfare ministry (Ministry for Children and Family Development) gradually deny families access to their removed children, a process referred to as "attenuation." There are programs such as Family Group Conferencing and ROOTS that assist in finding family members who could care for their young ones. While current child protection practice often involves time constraints that inhibit workers from going out into communities, building relationships and knowing families, these processes could be supported fiscally for the benefit of Aboriginal children. In cases where adoption is necessary, both children and young mothers could be "adopted" in ways that do not separate families and cause lifelong grief and disruption. This will be discussed further in the section on recommendations.

\section{The New Missionaries}

Aboriginal children are often fostered in white Christian homes. The Christian religions are often monotheistic and do not encourage the worshipping of any gods other than their own. While Aboriginal children may be encouraged to accept Jesus into their hearts, is there also room for the spirit of the mask?, spirit guides?, nature spirits? Do the religious values in the mainstream foster home facilitate the ongoing development of a Native spirituality which may be consider "pagan"? Developmentally speaking, can children maintain the openness of a both/and, rather than either/or, mentality when it comes to honouring the beliefs of their birth family and a new foster family? And without this kind of openness, can Aboriginal children thrive into adulthood avoiding a major crisis of identity leaving him/her with no foundation and becoming vulnerable to the typical trappings of people lost on Canadian streets such as East Hastings.

In the fostercare system this situation is exacerbated by the temporal limitations placed upon the provision of care. Today, a youth in care remains in care only until their age of majority (19). At that time they are passed over to the "welfare" system. Natural families 
maintain contact and connections with their children throughout their lives, providing a natural extended support system which is functionally denied the child in care when they reach the arbitrary age of nineteen. So, not only does the present system create an artificial environment, removing present familial supports but it also perpetuates this by cutting the child in care adrift without the benefit of future supports (other than the pittance of welfare). In addition to being overrepresented in child welfare, Aboriginal people often end up overrepresented in the prison system, moving from one institutional residence to another.

\section{So What Do Aboriginal Families Say?}

Many Aboriginal parents who have had their children removed are startled by the way they are held up against mainstream Canadian foster families who chauffeur children around from appointment to recreational activity to respite care to the psychologist's appointment. Cross-culturally, Aboriginal family life may appear inactive by the relative dearth of extracurricular, recreational activity. In fact, playing outside with other children on the block is often seen as dangerous or neglectful by mainstream standards. Also in fact, many Aboriginal families (not just parents, but entire families) have their children removed permanently because they cannot relate to the European-Canadian standards of parenting, and normal aspects of worldview and behaviour are labelled dangerous or neglectful (fishing, carving, walking home from school, playing outside, having younger children supervised by older children, being discriminated against in medical appointments for racial and linguistic reasons [thus being unable to advocate for children's health needs], missing school to attend big house ceremonies, not having a big house or a separate room for each child, etc). An example of this myopic view occurred during an investigation on a reserve in northern Alberta. The children had been coming to school unwashed and in dirty clothes.

The child protection worker assigned to the investigation was quite concerned about the hygiene of these children and wanted to place them in care. It was recommended to the social worker that she needed to conduct a home visit. During this visit the social worker discovered that the family relied on a creek for their water supply. The quarter mile walk to the creek in -50 weather, having to chop the ice and then having to carry the water to the cabin explained why bathing and washing clothes was a weekly, not daily routine.

\section{We Are Not Resilient! - We Are Fed Up}

We often hear that "it is amazing how resilient children are!" Yet, do we say that the ones who don't make it aren't resilient, or that in their state of vulnerability, they were overpowered by violence and cruelty in a system that did not attend to their needs adequately? Perhaps the biggest difference between the mainstream Canadian foster system and the residential school system is that many Aboriginal children attended only one residential school. The average Aboriginal child in foster care may experience between three and thirteen families before the age of nineteen. Then, according to the research, they go home to their birth family if they can still find it. Many children forget who they are, but they do maintain the urge to find out who they are when they are cut loose by the system upon reaching the age of majority. At the same time, they become experts in the area of heartbreak from broken attachments. Love becomes something elusive while children become experts at emotionally distancing themselves from each new set of temporary caregivers. This ambivalence was documented in a poem by Richard Cardinal while in the care of the state:

\author{
Love can be gentle as a lamb, or ferocious \\ as a lion \\ It is something to be welcomed: it is \\ something to be afraid of \\ It is good and bad \\ Yet people live, fight, die for this \\ Somehow people can't cope with it \\ I don't know - I think I would not be happy \\ with it
}

Yet I am depressed and sad without it

Love is very strange 
The authors of this paper are startled by the unsettling qualitative similarities between the residential school and the present day foster home, from a systemic perspective. That is, we do not assert that individual foster parents possess the general intent or values found in the Canadian residential schools; nonetheless the outcome is often the same. It's nothing personal, it's just that the kids can't take it anymore. We are fed up - they are giving up.

\section{Recommendations}

When we look deeply, we see that we are at a crisis point in the way we are living on the Earth. Most critically, we need to move from a culture of problem solving to one of visioning and creating the world we want. In terms of our practice, every 'helping' interaction between professions and Aboriginal families needs to be helpful, restorative, educational and curative. The work of Richardson and Wade (2007) shows that practice must be grounded in an understanding of the importance of human dignity and psychological safety, including a person's need for sovereignty, autonomy in decision making, and respect. Too often, families are judged from outside their cultural frame and are deemed to be deficient. Psychological tools, developed through the period of empire, are used continuously against Aboriginal and other marginalized people and to assess not capacity but deficiency.

These assessment tools are used by child protection professionals to amplify weakness and dysfunction while ignoring "responsivity" (an individual's many forms of response to challenge and blessings), while ignoring strength and while ignoring the social context and the blatant power imbalances between workers and families. Therefore, in order to interventions to be curative, thorough steps must be taken to attend to client dignity and to equalize power imbalances. Under such conditions, the real work can begin.

Along with individual and familial capacity, helping interventions can also build community capacity, which is necessary if things are to be different for Aboriginal children. Through "cleaning up" our practice and working in ways that actually preserve and strengthen extended families and communities, we help families to help themselves. With increased wellness and improved White/Aboriginal relations (free of racism, Euro-centrism and economic marginalization) true collaborations may emerge. Under improved conditions, all individuals will begin to care for the young ones, as well as the Earth, in a loving and thoughtful way. On a spiritual level, separation is the cause of much of our planetary grief; solutions will not come from continuing to separate children from their families, from their community and from their lands, traditions and spiritual practice.

That being said, as a society we can re-arrange fostering arrangements so that they are temporary and include parents and children rather than just children. We can advocate for housing that will support parent mentoring and multi-family cooperation, as in times past. We can ask that those who foster children receive regular clinical supervision for their own ongoing support and education, for the benefit of the children. We can support grandparents financially to care for children with support and alter our views about paying strangers and not family members to look after the young ones. We can legislate cultural plans and connective agreements between caregivers and Aboriginal communities, to maximize a child's possibility of cultural education.

Finally, we need to develop appropriate strategies to assist mothers in cases of paternal violence. Mothers who are victims of violence and abuse are typically held accountable for "failing to protect" their children from violence, even though they are all victims of the same perpetrator (Strega, 2006). As well, research by Coates and Wade (2004) has shown that professional language is used to obscure responsibility for violence, to cover up evidence such as client resistance to violence, and to blame the victims. Professionals can become much more clear in their positioning and handling of cases of spousal violence in order to work appropriately and effectively with cases of child protection. Community and social responses that enhance safety for victims and (e.g. mothers, fathers who are victims of spousal violence that is not self-defence, and children) hold perpetrators accountable for violence and healing are essential. However, both practice change and practice continuity sit within the "colonial container." Canada cannot continue to destabilize families through the ongoing disregard for Aboriginal treaty rights related to fishing, hunting, and community provision and 
wonder at the high levels of familial breakdown. If, as an arm of the state, child protection workers make Aboriginal parents redundant while wondering why these parents don't' "step up to the plate" and "just get over" the multiple losses inflicted upon them and look after their children. Meanwhile, we have to address issues of sub-standard housing, poverty, and unequal access to the law, to safety, to nutritious food and to medical care. When holistic principles of social justice (e.g. anti-racism \& authentic restoration for genocidal violence) are advanced, including the end of corporate pressure on Aboriginal lands and minerals, things will improve for Aboriginal children in all forms of care in Canada. Until then, Canada will continue to perpetuate assimilation for easier access for corporations to what we are standing on (land, minerals, oil, etc).

Today, Richard's former home of Fort Chipewyan sits on the shore of toxic waters from industry and people are getting sick at alarming levels (Brethour, 2006). Now more than ever, children's preservation is linked to environmental preservation and we are called to be even more thoughtful and holistic in the task of child protection. The memory of Richard Cardinal calls us to accountability in our sacred work with children.

\section{Endnotes}

1. At the time of Richard's passing (1984) Aboriginal people comprised $3.5 \%$ of Alberta's population, and $37.5 \%$ of the children who were wards of the state. Today (2003) in British Columbia, the figures are ...

2. More information about Richard's life can be found in the National Film Board video "Richard Cardinal: Cry From A Diary of a Metis Child, directed by Alanis Obomsawin

3. In 1919, the Governor-in-Council amended the law to lease reserve lands to mining companies without band approval. In the 1920s, laws ensured that "squatters" on reserve lands (e.g. Aboriginal people who went there to fish) were jailed. In 1936, responsibility for 'Indian Affairs' was transferred from the Department of the Interior to the Department of Lands, Mines \& Resources (RCAP, 1996, p. 285)
4. Not only as having special needs, but as being "special needs" in a vernacular, totalizing description of self.

5. The DSM 4 is the diagnostic manual of the American Association of Psychologists. Often these diagnoses are given by people who do not have the credentials to assign diagnoses. Once a particular diagnosis is entered upon a file, it is rarely removed and continues to influence future decisions.

6. The attack on the safety net has meant that funding for services such as supervised visits has been erratic. In some cases, parent/child visits are denied because supervised visitation programs have not been funded. Then, in court, the absence of these visits is sometimes used against the parent in their efforts to retain custody of their children.

7. And, in cases of paternal violence, mothers are often held responsible for the violence under "failure to protect" laws. This means that children are removed from mothers who are the victims of violence while society does not move to assist victims. The misuse of "failure to protect" legislation has been documented by Sue Strega (2005) at the University of Victoria School of Social Work.

8. Kinnear (200) tells, "As we were walking something quite extraordinary happened. We looked upwards and saw the word "SORRY" being written in the sky. It was simply overwhelming!"

\section{Bios:}

Cathy Richardson is a family therapist and advocate in an urban Metis child and family services organization. She is also president of the Aboriginal Family Therapy Centre and has a doctoral degree in Child and Youth Care at the University of Victoria. Cathy is a researcher, writer and community educator. She has worked in the Yukon with the Kaska survivors of Residential Schools. She delivers Aboriginal cultural sensitivity training for Child and Youth Mental Health workers. She is married and has three children. Her Metis family is from Fort Chipewyan Alberta, where her mother was born and returns every year to collect birch bark for her baskets.

Bill Nelson has recently retired from an urban Metis child and family services organization on Vancouver Island. He has worked both in Alberta and British Columbia and 
has 32 years experience working in and on the periphery of the child welfare and mental health systems. He has spent his career as a social worker, a family therapist and a child welfare advocate. Bill is married, a grandfather and is currently working part time as a family therapist.

\section{References}

Amnesty International Stolen Sisters Report. Available online at: http://www.amnesty.ca/resource_centre/ $\underline{\text { reports/view.php?load }=\text { arcview \&article }=1895 \& \mathrm{c}=\mathrm{Re}}$ source+Centre+Reports

Annett, K. (2002). Love and Death in the Valley. Bloomington, Indiana, USA: Authorhouse.

Babb, L.A. (1996). Statistics on U.S. Adoption. The Decree, American Adoption Congress.

Blackstock, C., Cross,. T., George, J., Brown, I., Formsma, J. (2006). Reconciliation in child welfare: Touchstones of hope for Indigenous children, youth and families. Published Conference Paper. First Nations Caring Society of Canada with National Indian Child Welfare Association. Ontario.

Brethour, P. (2005). Why is cancer sweeping tiny Fort Chipewyan? Toronto: Globe and Mail. Available online at: http://mostlywater. org/why_is_cancer_sweeping_tiny_FortChipewyan.

Cameron, J., Davis, S., Nixon, M., Ruemke, G., (2006). Aboriginal-White relations and residential schools: A path to reconciliation. Langford, B.C.: City University.

Carriere, J. (2006). Promising practices for maintaining identities in First Nation adoption. In First Peoples Child and Family Review, 2007, 3(1), 46-64.

Carriere, J. (2005). Connectedness and health for First Nations adoptees. Paediatrics \& Child Health, 10 (9), 545-548.

Carriere, J. (2005). Connectedness and health of First Nations adoptees. Unpublished dissertation. Edmonton: University of Alberta.
Coates, L., Wade, A. (2004). Telling it like it isn't: obscuring perpetrator responsibility for violent crime. Discourse \& Society, 15(5), 3-30..

Cook, R. (1991). A national evaluation of title IV-E foster care independent living programs for youth. Rockville, MD: Westat Inc.

Courtney, M., Piliavin, I. (1998). Foster youth transitions to adulthood: Outcomes 12 to 18 months after leaving out-of-home care. Madison: University of Wisconsin.

Ferry, J. (2000). No easy answer to high Native suicide rates. Psychology and Behavioural Sciences Collection, 355 (9207).

Freundlich, M. (1998). Access to identifying information: what the research tells us. CWLAdoption News, 2(4).

Government of Canada. (1996). Royal Commission Report on Aboriginal Peoples. Ottawa: Royal Commission on Aboriginal Peoples.

Groza, V., Rosenberg, K. (1998). Clinical and practice issues in adoption: bridging the Gap between adoptees placed as infants and as older children. Westport, Connecticut, U.S.A.: Praeger.

Haig-Brown, C. (1998). Resistance and renewal. Surviving the Indian residential school. Vancouver: Tillacum Library.

Johnson, P. (1983). Native Children and the Child Welfare System. Ottawa, ON: The Canadian Council on Social Development.

Kinnear, A. (2002). Stories of sorry, forgiveness and healing. The International Journal of Narrative Therapy and Community Work, 2002, 1, 3-6.

Kirmayer, L.J., Brass, G., Tait, C. (2000). The mental health of Aboriginal peoples: Transforamtions of identity and community. Canadian Psychiatry, 45, 607-615.

Lacmouche, J. (2002). Environmental scan of Metis health information, initiatives and programs. A report prepared for the National Aboriginal Health Organization. Ottawa, ON. Retrieved October 15, 2004 from the World Wide Web: http://www.naho. ca/english.research_papers.php. 


\section{A Change in Residence: A Paper to Provoke Thought and Systemic Change}

Lee, R., Lee, S. (2000). Social connectedness, dysfunctional interpersonal behaviours, and psychological distress: Testing a mediator model. Journal of Counselling Psychology, 48, 310-318.

Maracle, S., Craig, B., (1993). A strategy for Aboriginal family healing. Ottawa: ON.

Morley, J., Kendall, P. (2006). B.C. Child and Youth Review Report. Available online at: www.childyouthreview. ca/down/BC Children and Youth Review Report FINAL April 4.pdf.

National Film Board. (1984). Richard Cardinal: Cry from a diary of a Metis child. Ottawa, Ontario:National Film Board.

Palmer, S. Cooke, W., (1996). Understanding and countering racism with First Nations children in outof-home care. Child Welfare, 75(6).

Reid, M. (2005). First Nations Women Speak, Write and Research Back: Child welfare and decolonizing stories. First Peoples Child and Family Review, 2(1).

Resnick, M.D., Harris, L.J., Blum, R.W. (1993). The impact of caring and connectedness of adolescent health and well being. Journal of Paediatric \& Child Health, (Suppl 1), S3-9

Richardson, C., Wade, A. (2007). Safety in Collaborative Practice with Aboriginal Families. In press. Restorative Directions, 3.

Richardson, C. (2005a). Cultural stories and Metis self creation. Journal of Relational Child and Youth Care, 18(1), 55-63.

Richardson, C. (2004). Becoming Metis: The relationship between the sense of Metis self and cultural stories. Victoria: University of Victoria unpublished dissertation.

Richardson, C. (2003). Stories that map the way home. Cultural Reflections, 5, 21-27.

Richardson, C. (1999). To all mothers who have lost children - to all children who have lost mothers. In (ed. Denborough) Working With The Stories of Women's Lives. Adelaide, Australia: Dulwich Centre, 167-177.
Todd, N., Wade, A. (1994). Domination, deficiency and psychotherapy. The Calgary Participator, 4(1). 37-46.

Timpson, J. (1995). Four decades of literature on Native Canadian child welfare: Changing Themes. Child and Welfare, 74(3).

Timpson, Joyce. (1990). Indian and Native Special Status in Ontario's Child Welfare Legislation: An overview of the Social, Legal and Political Context. Canadian Social Work Review, 7(1).

United Nations Convention on the Rights of the Child. Available online at: http://www, anationalvoice.org/ rights/rotch./2.htm.

Wade, A. (1995). Resistance knowledges: Therapy with Aboriginal persons who have experienced violence. Canadian Western Geographical Series, 31, 167-206.

Yellowhead Tribal Services Agency. (2000). From the Heart. Video. Edmonton, Alberta. 